\title{
Periodic Variations of Pressure, Wind and Rainfall Observed at Miyakojima during the Second Miyakojima Typhoon
}

\author{
By Yasushi Mitsuta \\ Disaster Prevention Research Institute, Kyoto University, Kyoto \\ and \\ Sadao Yoshizumi \\ Meteorological Research Institute, Tokyo \\ (Manuscript received 17 July 1973)
}

\begin{abstract}
During the passage of the Second Miyakojima Typhoon the barograph at Miyakojima recorded a pronounced pressure oscillation with the period of about $50 \mathrm{~min}$ on September 5 , 1966. The recorded oscillation extended over half a day and had a maximum double amplitude exceeding $10 \mathrm{mb}$. Simultaneously, wind and rainfall intensity showed periodic variations with the approximately same period, too.

It is shown that the periodic variations of these elements were associated with the counterclockwise rotation of an elliptical eye revealed by radar observation.
\end{abstract}

\section{Introduction}

During the passage of a tropical cyclone a barograph trace usually describes a smooth $V$ shaped variation on the time scale of about half a day. Pressure variations with various shorter periods are frequently found out to be superimposed on such a smooth variation. One with a large amplitude has been known as "pumping" of the barometer (Tannehill, 1956). Fujita (1952) classified them into two groups, i.e., oscillatory and non-oscillatory perturbations.

Oscillatory pressure perturbations include the barometric ripples with the period of $10 \mathrm{~min}$ to one hour and the gusty oscillations with the period of one sec to $5 \mathrm{~min}$. The latter is considered as the pressure fluctuation due to the aerodynamic effect of strong gusty winds (Fujita 1952). However, the former type of pressure oscillation has not been fully understood yet. According to Deppermann (1939), about one-third of barograms of tropical storms which recorded a minimum pressure of lower than $740 \mathrm{mmHg}$ $(986.6 \mathrm{mb})$ showed a pressure oscillation with the period of 10 to $30 \mathrm{~min}$. A spectacular example of such oscillation is that observed at Naha during Typhoon Emma of 1956 (Jordan, 1962), which had a period of 20 to $40 \mathrm{~min}$ and maximum double amplitude of about $9 \mathrm{mb}$.

Recently the most spectacular one of pressure oscillations that have ever been known was recorded at Miyakojima on September 5, 1966 during the passage of the Second Miyakojima Typhoon (Typhoon 6618, Cora) (Mitsuta and Yoshizumi, 1968). The barograph described remarkably regular oscillation with the period of about $50 \mathrm{~min}$, which extended over half a day and had a maximum double amplitude exceeding $10 \mathrm{mb}$. In addition, wind and rainfall intensity also showed appreciably periodic variations.

In the present paper, a detailed analysis will be made of the periodic variations of meteorological elements observed at Miyakojima during the Second Miyakojima Typhoon. It will be also shown that these variations have a definite phase relation to each other and that they are associated with rotation of the elliptical eye of the typhoon revealed by radar observation at the Miyakojima Weather Station.

\section{Periodic variations of meteorological elements}

The Second Miyakojima Typhoon, which brought about the pressure oscillation at Miyakojima, appeared as a weak tropical 
depression to the northeast of Guam Isl. on August 29, 1966. The depression developed into a typhoon on Aug. 31 and continued to move on northwestward toward the Southwest Islands, its central pressure deepening. On the morning of September 5 when it hit Miyakojima, it attained its maximum intensity of $918 \mathrm{mb}$. The typhoon moved west-northwestward crossing the East China Sea until it landed on the Continent of China on Sept. 7 and filled up rapidly.

Fig. 1 shows the barogram which was recorded at the Miyakojima Weather Station during the typhoon on September 5, 1966. In this figure pronounced pressure oscillations with the period of about one hour stands out clearly from the gradual variation that should be associated with the typhoon passage. The pressure oscillation is very much more spectacular than that reported by Jordan (1962) in the amplitude and the duration. It lasted for a long time of about 12 hours from 05 to 17 JST on the 5 th.

In Fig. 2 is reproduced the wind record at Miyakojima. During the occurrence of the pressure oscillation wind direction generally veered from the northeast to the south and wind speed did not decrease to calm, indicating that the center of the typhoon approached from the southeast and passed on the southwest of this island toward the northwest. It can be seen

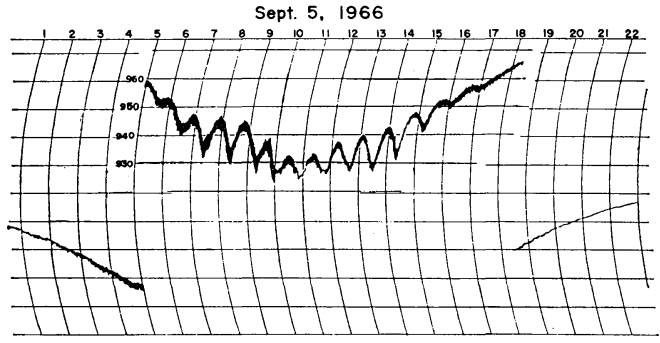

Fig. 1. The barogram recorded at the Miyakojima Weather Station on September 5, 1966. easily in Fig. 2 that the wind underwent periodic fluctuation in speed and direction both with nearly the same period as that of the pressure oscillation, and that the variation in wind speed began to be seen at about the same time when the pressure oscillation did.

It is also evident from a regular stepped character of the rainfall curve (Fig. 3) that there occurred markedly periodic variation in rainfall intensity at the Miyakojima Weather Station.

The fact that the variations of these elements have nearly the same period suggests that they are closely related to each other. In order to make clear the relationship, Figure 4 was prepared. In this figure a smoothed curve represents the running mean of 11 readings at 10-min intervals, i.e., the average value over about two periods, and a deviation is one from the smoothed value thus estimated. Winds were read out at the middle points of broadly fluctuating traces.

It is clear in Fig. 4 that the pressure oscillation

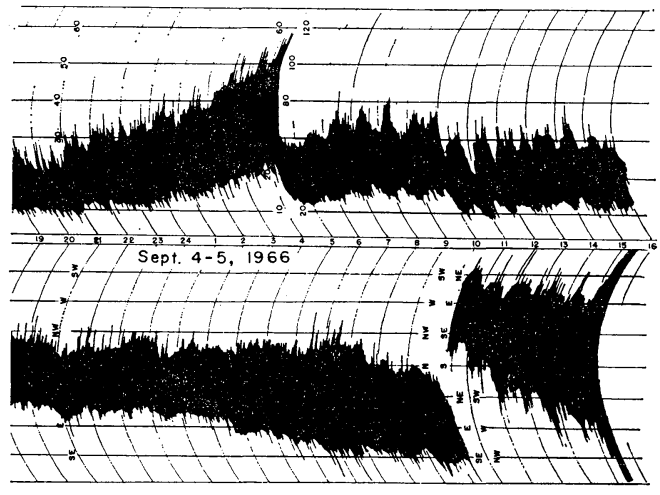

Fig. 2. The wind record at the Miyakojima Weather Station on September 4-5, 1966. Wind speed recording range is switched from $60 \mathrm{~m} / \mathrm{sec}$ into 120 $\mathrm{m} / \mathrm{sec}$ full scale at $0420 \mathrm{JST}$ on the 5th.

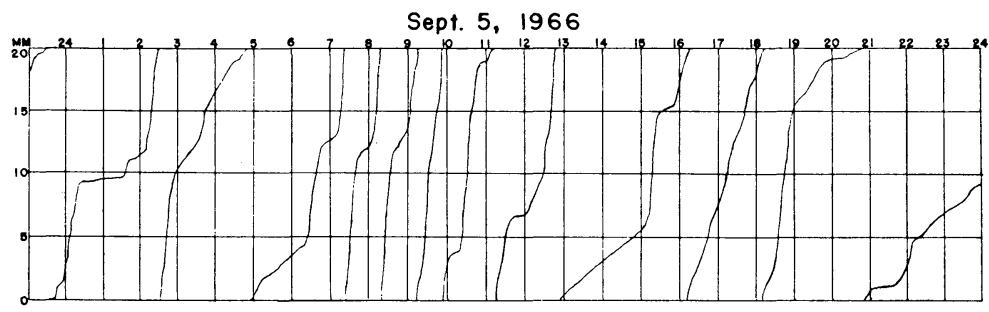

Fig. 3. The rainfall record at the Miyakojima Weather Station on September 5, 1966. 

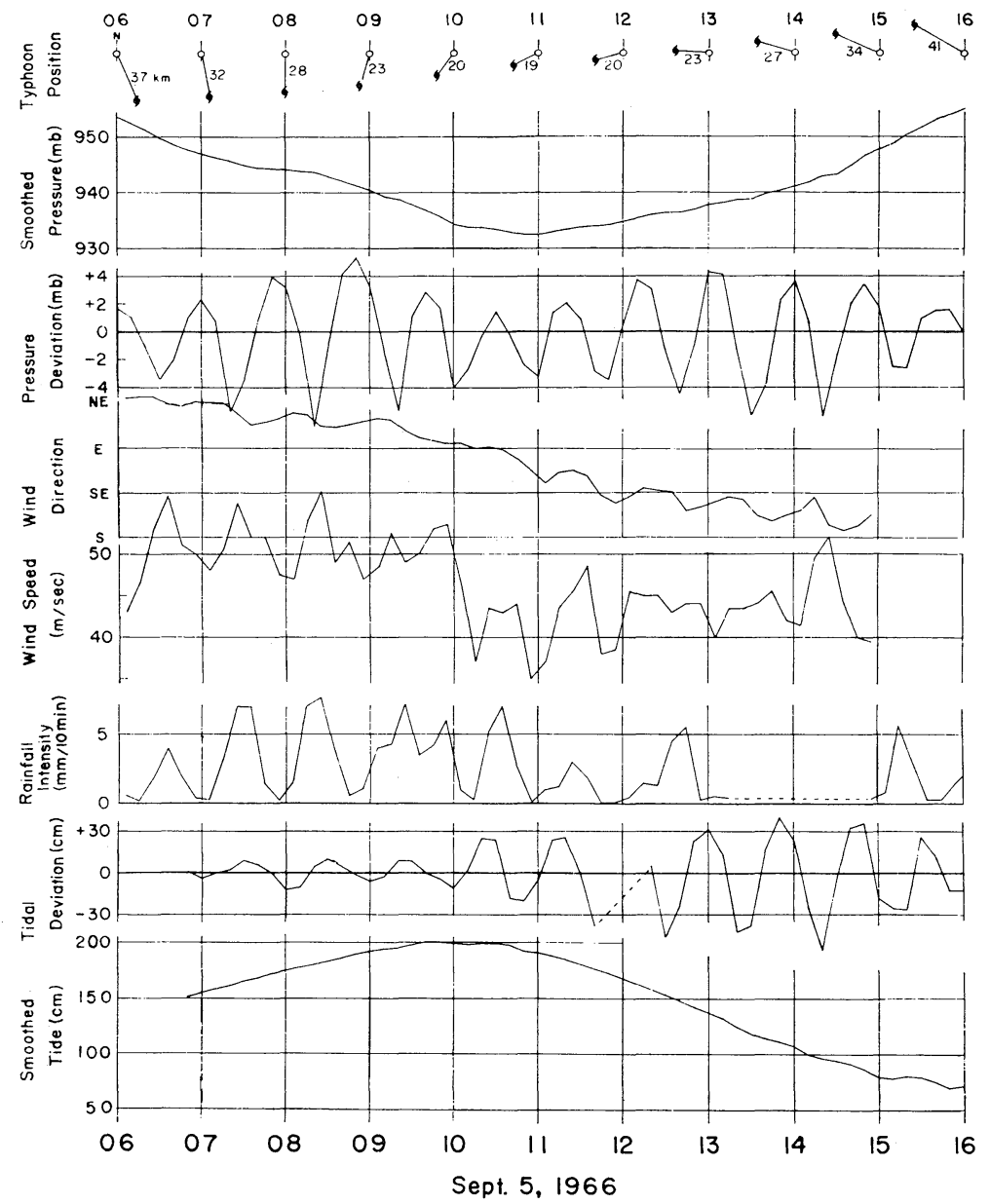

Fig. 4. Detailed change of meteorological elements at Miyakojima.

shows the two amplitude maxima of about $\pm 5 \mathrm{mb}$ at about two and a half hours before and after the time of smoothed pressure minimum at 1100 JST. As the smoothed pressure decreases, that is, the typhoon approaches toward Miyakojima, the pressure oscillation increases in amplitude to the first maximum at about 0830 JST and then decreases to a minimum of $\pm 2 \mathrm{mb}$ at about 1100 JST. Once the smoothed pressure rises, the oscillation begins to grow again until its amplitude reaches the second maximum at about 1330 JST. Thereafter it decays gradually.

As can be seen from Fig. 4, it took 640 minutes from 0615 to 1655 JST for the pressure oscillation to undergo 12 periods completely. Therefore, the averaged period of the pressure oscillation is estimated to be $53 \mathrm{~min}$. Relation between the pressure variation and the changes of other elements is also seen in this figure. While the pressure is falling, wind deflects northward, that is, the radial component of the disturbed wind is inward. While the pressure is rising, on the other hand, wind deflects southward, that is, the disturbed radial component is outward. Such phase relation of wind direction was kept up with the pressure variation until 1500 JST. But it cannot be confirmed whether such relation was still maintained thereafter because unfortunately the wind-mill type anemometer was blown down by strong winds about 1530 JST and hence the traces for one hour before that time seems to be unreliable due to the swaying of the wind vane.

The phase of the variation of wind speed to that of pressure turned reverses two times at about 0930 and 1230 JST. Wind speed shows a variation out of phase with the pressure oscillation until about $0930 \mathrm{JST}$; that is, stronger winds 
blow at the time of the pressure minima and weaker winds at the the pressure maxima. During the period from 0930 to 1230 JST the phase of wind speed is inphase and wind speed is stronger when the pressure deviation is positive and weaker when the pressure deviation is negative. At about 1230 JST the wind speed comes to have a reverse phase with the pressure. The wind speed trace is also not available owing to the anemometer blown off.

The rainfall intensity showed a periodic variation similar to the wind speed; that is, from about 0930 to 1230 JST rain was heavier when the pressure was higher and lighter when the pressure was lower. Before and after that period the relation between both variables was opposite and the maximum intensity of rainfall and the minimum of the pressure coincided in occurrence time. However, the rainfall record from 1300 to 1500 JST indicates a constant intensity. According to the staffs of the weather station, it is said that some obstacles fallen in the receiving funnel of the rain gauge prevented the precipitating water from flowing smoothly into the gauge.

In the uppermost part of Fig. 4, the position of the typhoon center relative to the Miyakojima Weather Station determined by Mitsuta and Yoshizumi (1968) is shown. During the occurrence of the pressure oscillation the center was located within $50 \mathrm{~km}$ from the station. The estimated distance between the center and the station was about $25 \mathrm{~km}$ at the times when the amplitude of the pressure variation showed the maximum, and about $22 \mathrm{~km}$ when the phase changes of wind speed and rainfall intensity occurred.

As shown in the lowermost part of Fig. 4, the tidal record draws alternate rising and lowering of the sea level with the period of about $50 \mathrm{~min}$. Its double amplitude, which did not exceed $30 \mathrm{~cm}$ by $1000 \mathrm{JST}$, increased gradually toward a maximum of $80 \mathrm{~cm}$ at 1400 JST and then decayed rapidly. Further description will not be given in the present paper, though it is an interesting phenomenon to reveal the mechanism of the high tide caused by the typhoon.

\section{Rotation of an elliptical eye of the typhoon}

Radar observations often reveal that the tropical cyclone has not a circular but an elliptical eye rotating counterclockwise. Sadowski

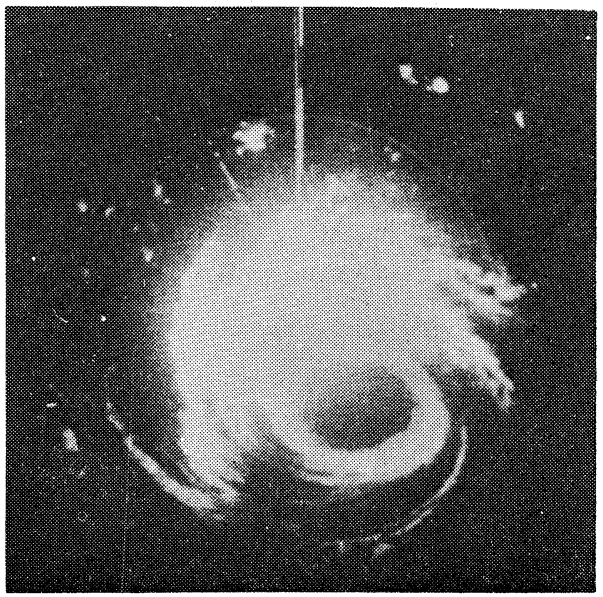

Fig. 5. Radar photograph taken at Miyakojima at 0453 JST on September 5, 1966.

(1962, 1964) reported that the configuration of the eye changed from circular to elliptical and then the major axis rotated in the cases of some hurricanes. In a few typhoons Imakado (1966) found an elliptical eye rotating counterclockwise at a angular speed of one rotation per two to six hours.

It is very interesting that the Second Miyakojima Typhoon had an elliptical eye while the pressure oscillation was occurring. Fig. 5 is a radar photograph taken at Miyakojima at 0453 JST, Sept. 5, which reveal that the eye of the typhoon was elliptical. In addition, its major axis of the elliptical eye was rotating counterclockwise at an angular speed of half a rotation per about one hour, as shown in Fig. 6. Unfortunately radar observation could not be helped stopping at 0630 JST since strong winds made it difficult to scan the radar antenna. Consequently we have no continuous information on the size and the configuration of the eye after that time. However, some other discrete data are available, which were obtained by five weather reconnaissance flights from 0700 on the 5 th to 1102 JST on the 6 th. All flight reports after 0630 JST show that the eye of the typhoon was elliptical (see Table 1). It may be therefore inferred from these that the eye of the Second Miyakojima Typhoon remained elliptical during the period of one day and a half.

It is noteworthy that the rotation period of the eye is about twice that of the pressure oscillation. The rate of rotation is estimated to 


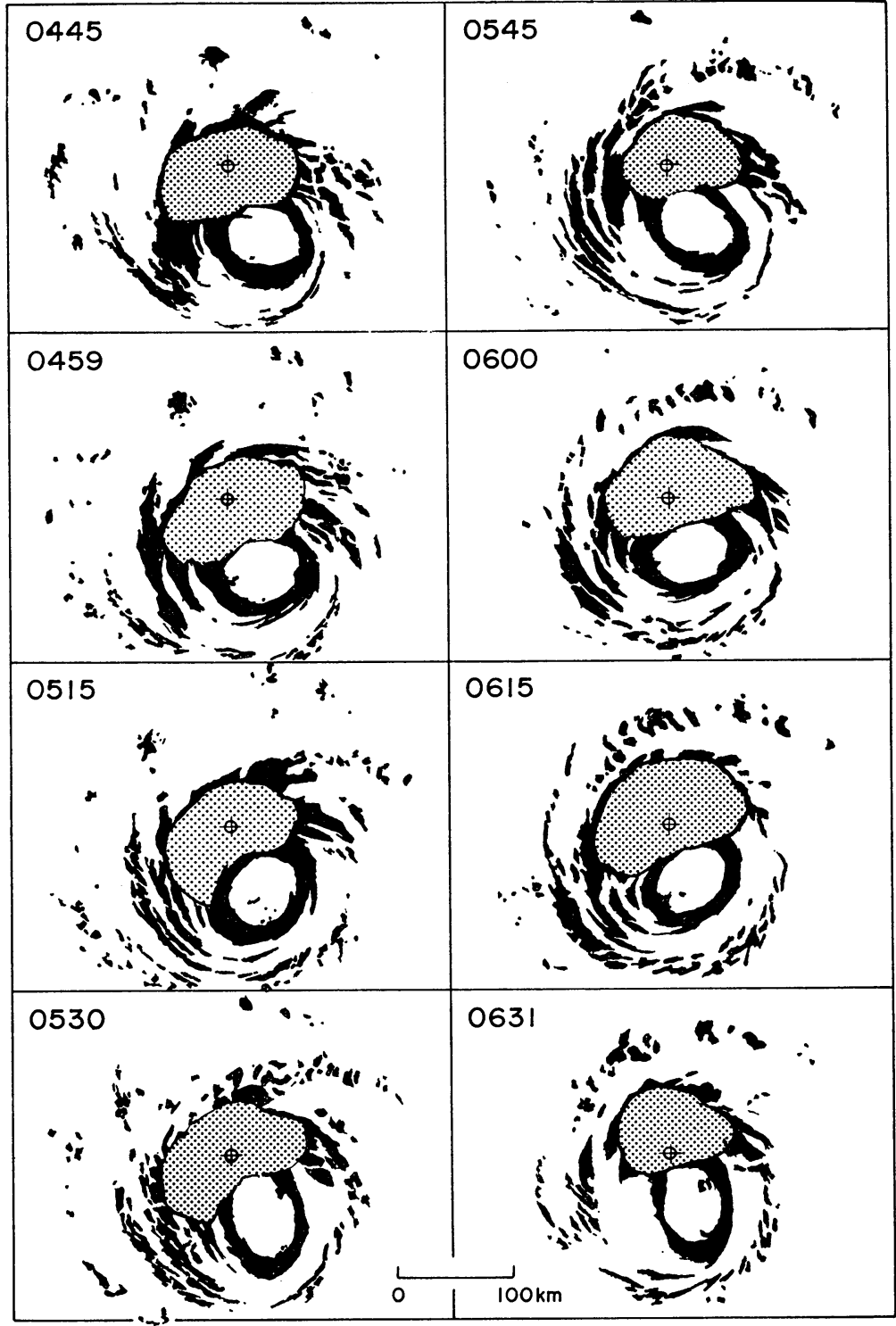

Fig. 6. Radar echo distribution during the period from 0445 to 0631 JST on September 5, 1966. The stippled area shows where radar echo is confused.

be 180 deg per $58 \mathrm{~min}$ from radar photographs taken from 0459 to 0631 JST. Furthermore, we can find out an interesting fact when we look over the correspondence between the phase of the pressure oscillation and the orientation of the elliptical eye during the period from 0500 to 0630 JST (see Figs. 1 and 6). At 0600 JST when the pressure maximum was observed, the major axis of the eye was oriented ENE-WSW and the Miyakojima Weather Station was situated on the side of the minor axis. At 0530 and
0630 JST when the pressure minimum was observed, the major axis was oriented NNW-SSE and the station was situated on the side of the major axis.

The above-mentioned facts lead us to the inference that the pressure deviation has a negative sign on the side of the major axis and a positive sign on the side of the minor axis. If such correspondence was hold after $0630 \mathrm{JST}$, the rotation rate of the eye relative to the earth can be evaluated from the period of the pressure 
oscillation by taking account of azimuth change of the typhoon center to the station due to its movement. During the 640-min period from 0615 to $1655 \mathrm{JST}$, the pressure variation underwent 12 periods, which should correspond to 6 rotations $(=360 \mathrm{deg} \times 6)$ and the azimuth change of the typhoon center was $142 \mathrm{deg}$.

Table 1. The configuration and the size of the eye reported by aircraft reconnaissance

\begin{tabular}{cc|c|c|c}
\hline Date & $\begin{array}{c}\text { Time } \\
\text { (JST) }\end{array}$ & Configuration & $\begin{array}{c}\text { Orientation of } \\
\text { the major axis }\end{array}$ & Size (n.m.) \\
\hline 4th & 1825 & circular & $\ldots \ldots$. & 34 \\
& 2225 & elliptical & E-W & $35 \times 32$ \\
5 th & 0700 & elliptical & E-W & $30 \times 20$ \\
& 1100 & elliptical & NE-SW & $30 \times 20$ \\
& 1800 & elliptical & NW-SE & $37 \times 26$ \\
6 th & 0634 & elliptical & NE-SW & $35 \times 20$ \\
& 1102 & elliptical & N-S & $30 \times 25$ \\
\hline
\end{tabular}

Thus the rotation rate relative to the earth is estimated to be $180 \mathrm{deg}$ per $57 \mathrm{~min}$ ( $=640 \mathrm{~min}$ $\times 180 \mathrm{deg} /(360 \mathrm{deg} \times 6-142 \mathrm{deg}))$. This estimated value is in good agreement with the rate determined from radar photographs, $180 \mathrm{deg}$ per $58 \mathrm{~min}$.

By the use of the rotation rate obtained above, the orientation of the major axis of the elliptical eye can be fixed for the period from 0500 to 1800 JST. The fixed orientation is illustrated at 30-min intervals in Fig. 7. For the period during which radar observation was not made, the estimated orientation can be compared with that obtained by three flights, as listed in Table 1 . Reconnaissance aircraft reported that the major axis was oriented $\mathrm{E}$ to $\mathrm{W}$ at $0700, \mathrm{NE}$ to $\mathrm{SW}$ at 1100 and NW to SE at 1800 JST, while the estimated orientation, shown in Fig. 7, at corresponding time is 074 to $254 \mathrm{deg}, 038$ to 218 deg and 154 to 334 deg (measured clockwise from

\section{Orientation of the Major Axis}

\section{of Elliptical Eye}

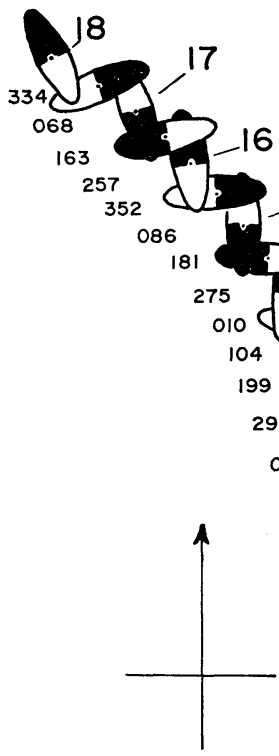

\begin{tabular}{lr}
\multicolumn{2}{c}{ RADAR } \\
0459 & $83-263$ \\
0530 & $177-357$ \\
0600 & $75-255$ \\
0631 & $166-346$
\end{tabular}
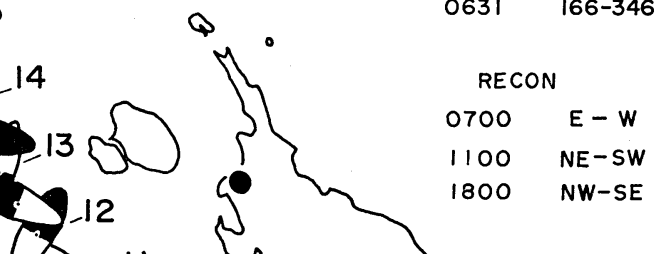

123
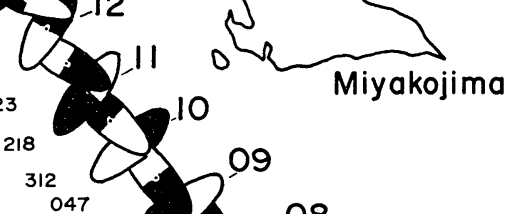

141

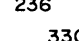

330
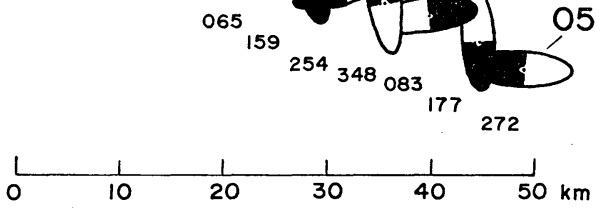

Fig. 7. The path of the Second Miyakojima Typhoon and the orientation of its elliptical eye. Small figures on the left indicate the orientation of the black part of the eye measured clockwise from the north. 
the north), respectively. This good agreement supports the inference that the elliptical eye continued to rotate as before 0630 JST*.

In the case of Typhoon Emma, Jordan (1962a) discussed possible causes of this type of pressure oscillation: 1) oscillatory motion or pulsation of the typhoon system, 2) dynamic pressure effects by topography, 3) convective cells in the eye wall, 4) wave disturbances propagating around the center and so on. He pointed out that it is difficult to explain the pressure oscillation in that case from 1)-3). Nevertheless, he could not obtain enough evidence to derive a definite conclusion.

In the present case, as mentioned above, radar observation made until 0630 JST revealed that the typhoon had an elliptical eye which was rotating counterclockwise. From comparing the rotation of the eye with the pressure oscillation it was inferred that the rotation of the elliptical eye was associated with the pressure oscillation and its one rotation produced two crests and two troughs on the barogram. This inference is supported by flight observations made after 0630 JST.

\section{Structure in the vicinity of the elliptical eye}

In the previous section it was shown that the pressure oscillation was associated with the rotation of the elliptical eye. In the present section we shall try to describe the structure in the vicinity of the elliptical eye. With the assumption of the steady state, the transformation from the temporal to the spacial change will make it possible to depict the distribution of meteorological elements on the basis of observed values at the Miyakojima Weather Station only. The assumption of the steady state does not seem to be unreasonable since the typhoon showed little change in the central pressure and a slight decrease in the size of the eye during

* Data given in Tabel 1 were taken from teletype data received at the Ryukyu Weather Bureau. According to Annual Typhoon Rerort of 1966 by U.S. Fleet Weather Central/Joint Typhoon Warning Center, Guam, the orientation of the major axis is NW-SE at 2225 JST on the 4th and at 0700 JST on the 5th. Thus this report means that the discrepancy between the reported orientation is about 45 degrees at 0700 JST on the 5th. But this discrepancy is not serious for the above inference. the pressure oscillation. The size is reported to be $50 \times 60 \mathrm{~km}$ at 0600 JST by radar observation, $36 \times 54 \mathrm{~km}$ at $1100 \mathrm{JST}$ and $47 \times 67 \mathrm{~km}$ at 1800 JST by flight observation (see Table 1 and Fig. 6).

Fig. 8 shows the time change of the relative position of the Miyakojima Weather Station to the center of the elliptical eye, which was determined from Fig. 7.

The distributions of meteorological elements were constructed based on the relative position of the station shown in Fig. 8. The pressure deviation distribution thus obtained is illustrated in Fig. 9. The observed pressure deviation is negative in the quadrants with the major axis and positive in the quadrants with the minor axis. Their extreme values are found out near $25 \mathrm{~km}$ from the center. The pressure deviation is the departure from the concentric pressure distribution by definition, so that Fig. 9 means that within $50 \mathrm{~km}$ from the center the isobars are ellipses whose major and minor axes coincide with those of the eye seen by the radar. The pressure deviation field shown in Fig. 9 does not mean that the typhoon has two pressure centers since the minimum pressure at trough is lower at lower smoothed pressure, i.e., decreases toward the eye center, as evident from Fig. 1.

The distribution of the 10-min rate of precipitation is depicted in Fig. 10, where an area with the rate of $2.5 \mathrm{~mm} / 10 \mathrm{~min}$ or more is hatched. It is evident from this figure that the rainfall area is of an elliptical ring whose width is wider on the side of the major axis and narrower on the side of the minor axis, similar to that shown in Fig. 6. The orientation of its major axis is coincident with that derived from the pressure oscillation. Such good agreement supports the inference that the pressure oscillation was associated with the rotation of the elliptical eye. The elliptical ring of maximum intensity, as seen in Fig. 10, has a longer diameter of $55 \mathrm{~km}$ and a shorter one of $40 \mathrm{~km}$. This estimated size is in good agreement with that reported by flight observation at 1100 JST.

From comparison between Figs. 9 and 10 it can be easily understood that the phase relation of rainfall intensity to pressure variation was reversed at the distance of about $22 \mathrm{~km}$ from the center. Rainfall is more intense in the areas of positive pressure deviation or in the direction of the minor axis inside the minor radius and in 


\section{Relative Position of}

Miyakojima Weather Station

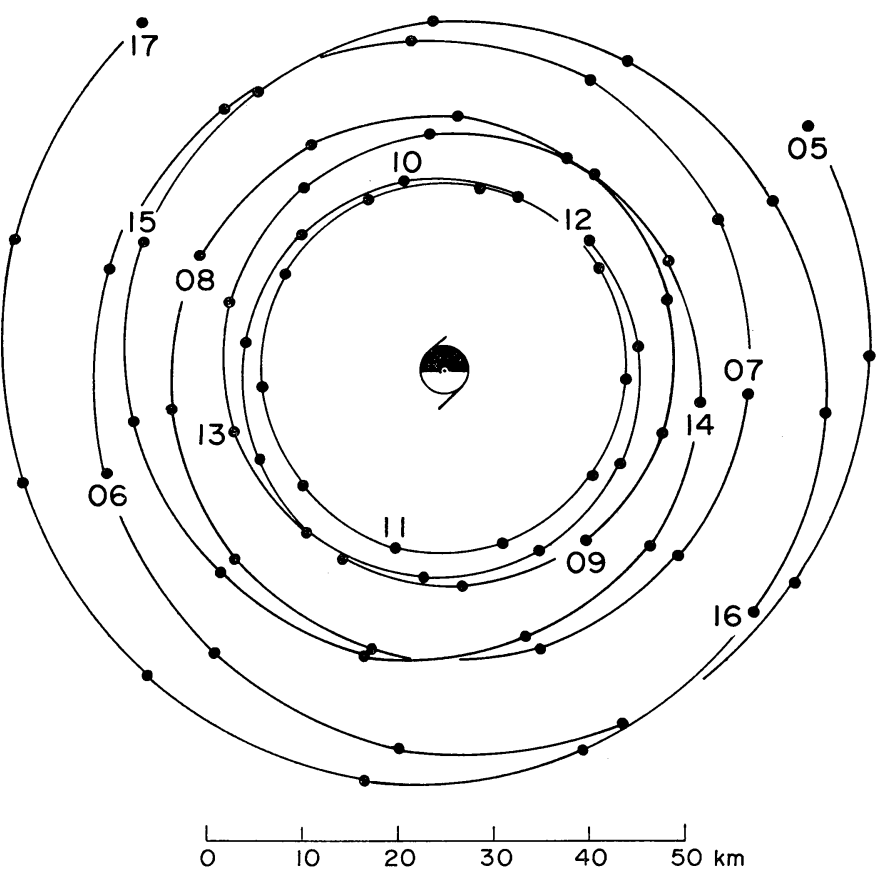

Fig. 8. Position of the Miyakojima Weather Station relativeto the elliptical eye during the period from 0500 to 1700 JST on Sept. 5. The black part of the eye shown in Fig. 7 is oriented upward.

Pressure Deviation
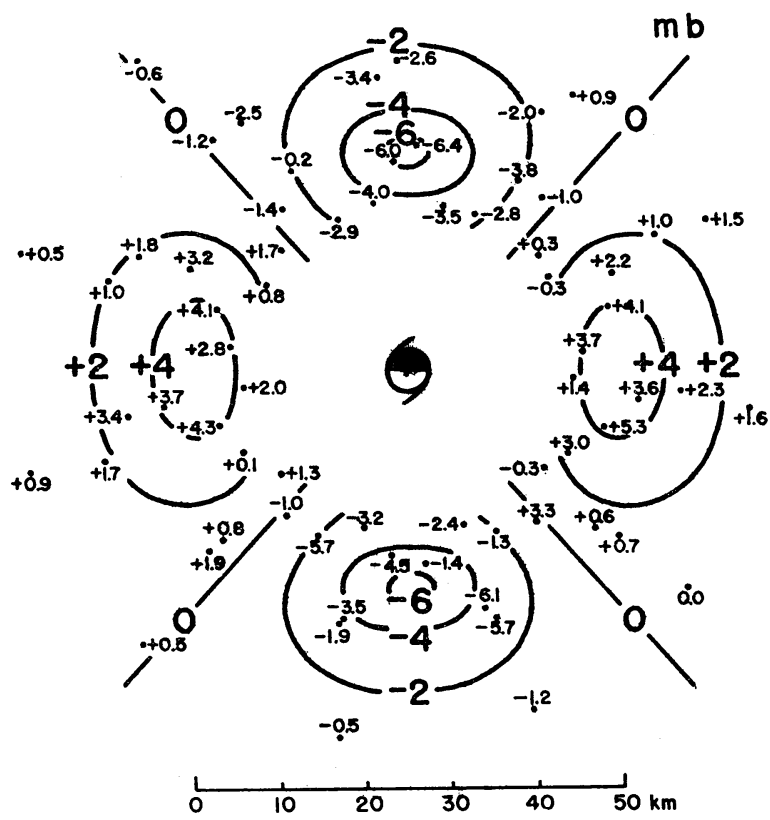

Fig. 9. Distribution of pressure deviation. The black part of the eye shown in Fig. 7 is oriented upward. 


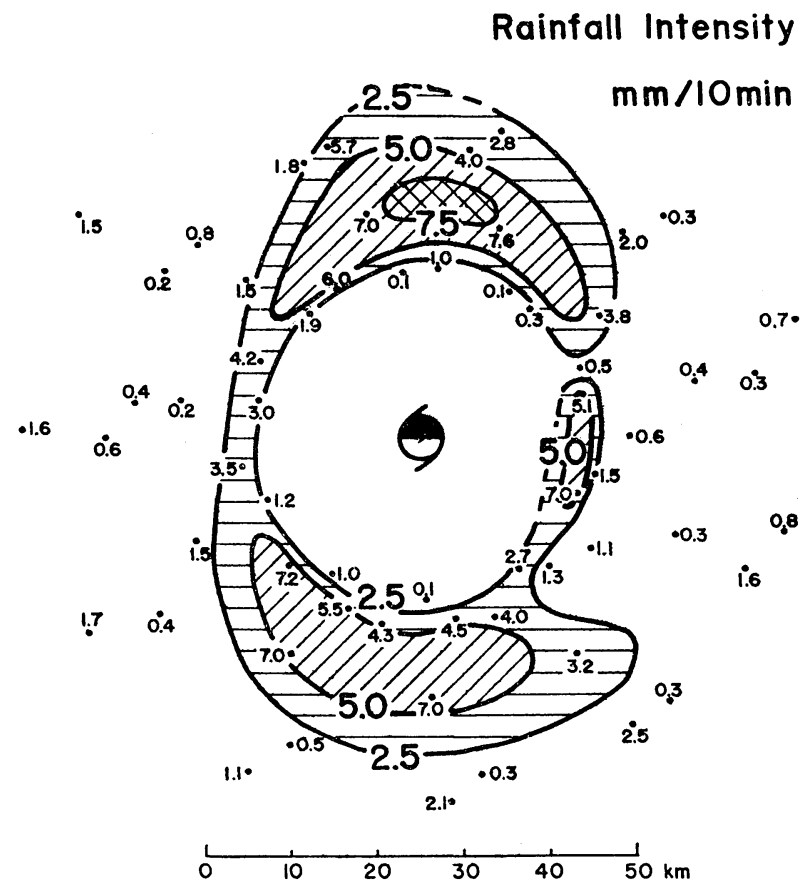

Fig. 10. Distribution of rainfall intensity (in $\mathrm{mm} / 10 \mathrm{~min}$ ). The black part of the eye shown in Fig. 7 is oriented upward.

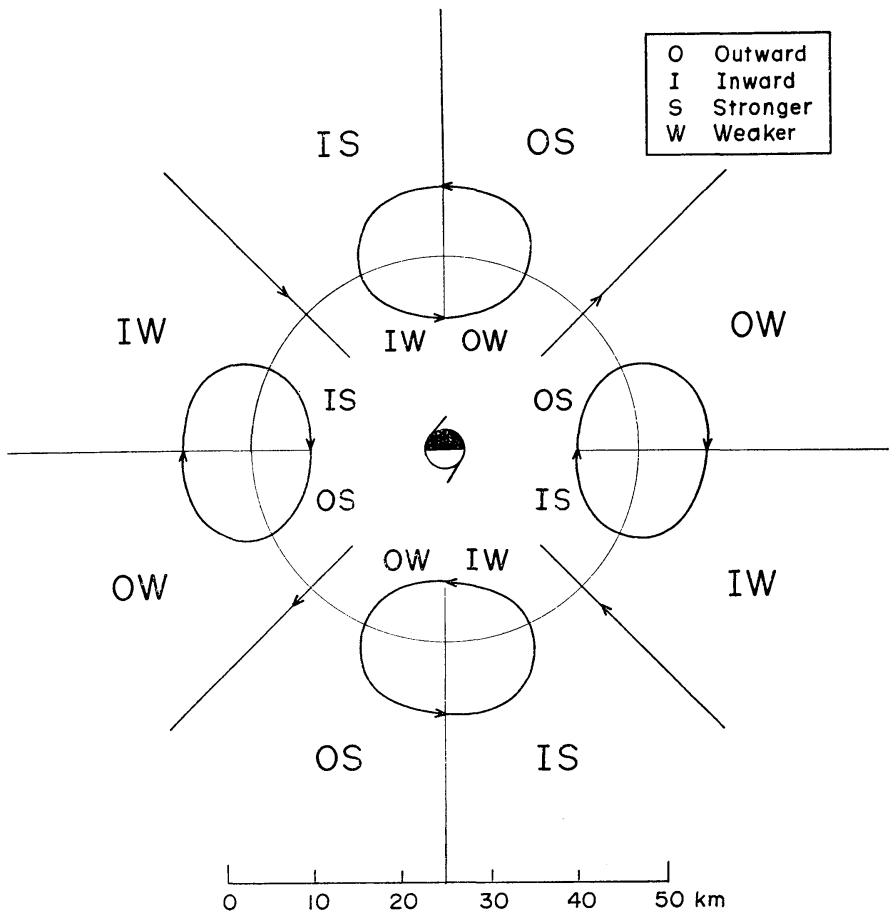

Fig. 11. Schematic illustration of the disturbed wind field. Its expected streamlines are indicated by solid lines with arrow. The black part of the eye shown in Fig. 7 is oriented upward. 
the areas of negative pressure deviation outside the major radius. The phase relation is not definite in the area between major and minor radii, as seen in Fig. 4.

Fig. 11 is a schematic illustration of the disturbed wind field. The expected streamlines (solid lines with arrow) are composed of four cells with its center at the radius of $22 \mathrm{~km}$. Two cells of the disturbed circulation on the major axis are of cyclonic sense and two ones on the minor axis of anticyclonic sense.

\section{Summary}

During the passage of the Second Miyakojima Typhoon the barograph at Miyakojima recorded a pronounced pressure oscillation on September 5, 1966. The recorded oscillation extended over half a day from 0500 to 1700 JST with the period of $53 \mathrm{~min}$ and had a maximum double amplitude of about $10 \mathrm{mb}$. Simultaneously wind and rainfall intensity also showed remarkably periodic variations with the nearly same period.

Radar observation made at the Miyakojima Weather Station until 0630 JST revealed that the typhoon had an elliptical eye which was rotating counterclockwise at the rate of half a rotation per about one hour. The comparison between the rotation of the eye and the pressure oscillation indicated that the observed pressure deviation was negative on the side of the major axis and positive on the side of the minor axis. Flight observations suggest the persistence of such correspondence between them after 0630 JST.

Distributions of rainfall intensity, disturbed pressure and wind accompanied by the elliptical eye was revealed by means of the transformation from the temporal to the spacial changes of their observed values at the Miyakojima Weather Station.

In the transformation the center of the elliptical eye was taken as the origin of the reference coordinate. As Hatakeyama, Imai and Masuda (1955) revealed, the centers of pressure and wind field does not always coincide with that of the eye in a moving typhoon. Therefore, there may be room to devise the procedure of transformation. In the present case, however, the discrepancy between the centers appears to be small due to the slow movement of the typhoon.
Also, the procedure of transformation seems to be justified by the obtained reasonable distribution of rainfall intensity.

\section{Acknowledgements}

The present study is based mainly on the data which were collected for the investigation of the disasters caused by the Second Miyakojima Typhoon directed by Prof. H. Ishizaki of the Disaster Prevention Research Institute, Kyoto University under a Grant in Aid for Fundamental Scientific Research from the Ministry of Education. The authors are grateful to Prof. R. Yamamoto of the Geophysical Institute, Kyoto University for valuable advice in the course of the present study and to the director of the Miyakojima Weather Station for supplying radar photographs. They would also express their thanks to Miss $\mathrm{H}$. Imai for drafting some of figures.

\section{References}

Deppermann, C.E., 1939: Some characteristics of Philippine typhoons. Bull. Amer. Meteor. Soc., 20, 303-307.

Fujita, T.T., 1952: Pressure distribution within typhoon. Geophys. Mag., 23, 437-452.

Hatakeyama, H., I. Imai and Y. Masuda, 1955: On some radar observations of Typhoon "Lorna". Proc. UNESCO Symposium on typhoons, 121-128.

Imakado, M., 1966: Detailed analysis of typhoon structure by means of weather radars. Geophys. Mag., 33, 99-106.

Jordan, C.L., 1962a: Surface pressure oscillation in tropical cyclones. National Hurricane Research Project, Report No. 50, 39-50.

- 1962b: Surface pressure oscillations during a typhoon at Okinawa. Mon. Wea. Rev., 90, 191-193.

Mitsuta, Y., and S. Yoshizumi, 1968: Characteristics of the Second Miyakojima Typhoon. Bull. Disaster Prevention Res. Inst., Kyoto Univ., 18, Part 1, 15-34.

Sadowski, A., 1962: Radar analysis of hurricane Donna's recurvature. National Hurricane Research Project, Report No. 50, 63-69.

, 1964: Evolution of hurricane Ginny as seen on WSR-57 radar at Charleston, S.C. Proc. 11 th Weather Radar Conf., 354-357.

Tannehill, I.R., 1956: Hurricane. Princeton University Press, Princeton, N.J., 308 pp. 


\section{第二宮古島台風通過時宮古島において観測された}

気压・風・降雨強度の周期的変動

光 田 寧
京都大学防災研究所
吉 住 禎 夫
気象研究所

第二宮古島台風通過中の1966年 9 月 5 日 5 時から17時までの 12 時間にわたり, 顕著な気圧振動が宮古島に括いて記 録された. 気圧振動の周期は約 50 分, 最大全振幅は $10 \mathrm{mb}$ を越えた。同時に風・降雨強度も気圧とほぼ同周期の周 期的変動を示した．これら要素の変動間に明確な位相関係の存在が認められる.

宮古島に括ける 5 日 6 時30分まで行われたレーダ一観測括よびその後の飛行機観測資料之の比較から, 上記気象要 素の周期的変動は, 約 1 時間に半回転の割で反時計迴りに回転していた長円形の台風の眼に伴うものであることが示 される. 宮古島に称いて観測された気象要素の時間変化を空間变化に变換することにより, 長円形の台風眼周辺の構 造が明かにされる。 